\title{
One-step Sustainable Preparation of
}

\section{Superparamagnetic Iron Oxide Nanoparticles}

\section{Supported on Mesoporous $\mathrm{SiO}_{2}$}

Elena Chamorro, ${ }^{a}$ M. José Tenorio,${ }^{b, \dagger}$ Lourdes Calvo, ${ }^{a}$ M. José Torralvo, ${ }^{c}$ Regino Sáez-Puche ${ }^{c}$ and Albertina Cabañas ${ }^{b *}$

${ }^{a}$ Dep. Chemical Engineering, ${ }^{b}$ Dep. Physical Chemistry, ${ }^{\mathrm{c}}$ Dep. Inorganic Chemistry, Universidad Complutense de Madrid, Avda. Complutense s/n, 28040 Madrid, Spain

${ }^{\dagger}$ Current address: Chemical, Energy and Mechanical Technology Dep, Universidad Rey Juan Carlos, c/Tulipán s/n, 28933 Móstoles, Madrid, Spain

* Corresponding author:

Albertina Cabañas, e-mail: a.cabanas@quim.ucm.es 


\section{ABSTRACT}

Superparamagnetic iron oxide nanoparticles (SPIONs) supported on high surface area mesoporous $\mathrm{SiO}_{2}$ are advanced materials of great interest in catalysis, adsorption and biomedicine. Here we present a new process to prepare $\mathrm{SPION} / \mathrm{SiO}_{2}$ materials by the impregnation and insitu decomposition of $\mathrm{Fe}\left(\mathrm{NO}_{3}\right)_{3} \cdot 9 \mathrm{H}_{2} \mathrm{O}$ on mesoporous $\mathrm{SiO}_{2}$ supports in a $25-50 \%$ mol ethanol $+\mathrm{CO}_{2}$ mixture at $523 \mathrm{~K}$ and $25.0 \mathrm{MPa} . \gamma-\mathrm{Fe}_{2} \mathrm{O}_{3}$ nanoparticles (NPs) of average size between 6-9 nm were distributed homogeneously on the supports. NPs deposited into the SBA-15 mesopores but mostly on the external surface of MCM-41. Materials prepared with the highest ethanol content were very homogeneous. Magnetic measurements confirmed the superparamagnetic nature of the materials at room temperature. The process proposed is sustainable and scalable, avoids tedious preparations and the additional high temperature treatment under a controlled atmosphere, as the metal decomposition is performed insitu in the $\mathrm{CO}_{2}$-expanded liquid mixture.

KEYWORDS: SPION, Supercritical $\mathrm{CO}_{2}$, Maghemite, Mesoporous Materials, $\mathrm{CO}_{2}$-expanded liquids. 


\section{Introduction}

Magnetic iron oxide nanoparticles (NPs) have great potential as magnetic recyclable nanocatalysts[1, 2], information storage materials[3], in adsorption/separation processes[4], and in biomedical applications[5, 6]. From the different iron oxides, maghemite $\left(\gamma-\mathrm{Fe}_{2} \mathrm{O}_{3}\right)$ and magnetite $\left(\mathrm{Fe}_{3} \mathrm{O}_{4}\right)$ present an inverse spinel structure and exhibit ferrimagnetic behaviour at room temperature with a net magnetic moment in absence of magnetic field, whilst hematite $\left(\alpha-\mathrm{Fe}_{2} \mathrm{O}_{3}\right)$ presents a corundum structure being weakly ferromagnetic. Magnetic NPs smaller than $20 \mathrm{~nm}$ have single magnetic domains and normally show superparamagnetic behaviour at room temperature (superparamagnetic magnetic iron oxide nanoparticles, SPIONs) with no remnant magnetization that could lead to agglomeration.

Magnetic NPs supported on high surface area mesoporous $\mathrm{SiO}_{2}$ materials do not aggregate, their stability to oxidation is enhanced and they are much easier to handle. The high surface and pore volume of ordered mesoporous $\mathrm{SiO}_{2}$ materials such as SBA-15 and MCM-41, their tunable periodic structures, uniform pore sizes and biocompatibility, turn them into ideal supports for catalysts, absorbents for pollutants or even excipients for drugs, expanding their applicability $[7,8]$. Furthermore, silica can be easily functionalized imparting new properties to the materials.

Supported iron oxide NPs have proved to be very active catalysts in the oxidation of alcohols, sulphides and thiols[9,10]. Similarly, surface modified mesoporous silica materials containing magnetic iron oxide NPs are efficient metal adsorbers[11]. These materials can be easily recovered by application of magnetic fields. Modern drug delivery formulations incorporating SPIONs and mesoporous $\mathrm{SiO}_{2}$ have been also proposed[12, 13]. These systems can be monitored in the organism by Magnetic Resonance Imaging (MRI) and directed by magnetic fields to the target 
organs. Because magnetic fields are weakly absorbed by life tissues, they can be applied to internal regions of the body. Local heating and hyperthermia can be also induced by application of an alternating magnetic field.

There are numerous publications on the preparation of $\mathrm{SPION} /$ mesoporous $\mathrm{SiO}_{2}$ composite materials by the wet impregnation of $\mathrm{SiO}_{2}$ supports followed by heat treatment[14-17]. In this method, uptake of the liquid metal precursor solution into the pores occurs thanks to the capillary pressure and for wetting liquids it happens spontaneously[18]. However, the relatively high surface tension and viscosity of most liquid solvents oftentimes hinders wetting of the support surface[19] and makes difficult the penetration of the metal precursor into the pores leading to nonhomogenous materials, making the process non-scalable. Drying of the impregnated support is also critical and can influence adversely the precursor distribution. Surface modification of the supports has been also performed prior to the impregnation to favour wetting and therefore precursor penetration[20]. Better results have been obtained using the two solvent approach[21]. In every method, the impregnated precursor must be further decomposed. Thus a strict control of the decomposition conditions and relatively high temperatures are employed in order to yield magnetic iron oxide, being difficult to get single phase materials[16]. Alternatively, aerogels generated by the simultaneous sol gel reaction of Si and Fe precursors have been also prepared[2224]. However, the saturation magnetization values of these materials in some cases can be quite low[25]. If structure directing agents are used, the presence of the Fe precursor may interfere with the silica formation and, at the same time, it may be difficult to reach single phase materials. Magnetic aerogels showing good properties have been also prepared incorporating preformed magnetic nanoparticles [26, 27]. Summarizing, most of these processes are multi-steps and require 
the use of relatively high temperatures as well as a strict control of the heating atmosphere, which turn the process complicated, difficult to scale-up and not sustainable.

In contrast, supercritical fluids have emerged as sustainable media in the preparation and processing of materials[28, 29]. Their tuneable density, lower viscosity and much higher diffusivity in comparison to liquids allow the preparation of advanced materials in a more sustainable way[30-32]. In particular supercritical $\mathrm{CO}_{2}$ is considered a sustainable solvent because it is non-toxic, inert, cheap and abundant (residue of the chemical industry), it can be recycled and it has low critical pressure and temperature $(304.2 \mathrm{~K}, 7.38 \mathrm{MPa})[33]$. Supercritical water, ethanol and methanol are other supercritical fluids frequently used.

Iron oxide NPs have been processed using different supercritical fluids[34]. Magnetic iron oxide NPs were successfully synthesized from different Fe salts using supercritical water[35-37] and alcohols[38-40] at temperatures from 523-673 K and pressures above $20 \mathrm{MPa}$. With respect to the preparation of iron oxide composite materials using supercritical $\mathrm{CO}_{2}$, Crowley et al. reported the preparation of $\mathrm{Fe}_{3} \mathrm{O}_{4} /$ silica materials from the decomposition of $\mathrm{Fe}$ carbonyl in $\mathrm{CO}_{2}+$ methanol mixtures at $773 \mathrm{~K}$ [41]. Carbon- $\mathrm{Fe}_{3} \mathrm{O}_{4}$ coaxial nanofibres were also prepared by the thermal decomposition of ferrocene in supercritical $\mathrm{CO}_{2}$ at $673 \mathrm{~K}$ [42]. Other authors have used hydrated metal nitrate precursors. These compounds are insoluble in pure $\mathrm{CO}_{2}$ but are soluble in mixtures of ethanol $+\mathrm{CO}_{2}[43,44]$. Sun et al. prepared $\alpha-\mathrm{Fe}_{2} \mathrm{O}_{3}$ nanotubes by impregnation of $\mathrm{Fe}\left(\mathrm{NO}_{3}\right)_{3} .9 \mathrm{H}_{2} \mathrm{O}$ on carbon nanotubes in a mixture of $\mathrm{CO}_{2}$ and ethanol at $398 \mathrm{~K}$ followed by calcination in air at $773 \mathrm{~K}$ [45]. The same precursor was also employed to anchor $\mathrm{Fe}_{3} \mathrm{O}_{4} \mathrm{NPs}$ on graphene foams[46] and on porous carbon[47,48]. 
Here we report the one-step preparation of mesoporous $\mathrm{SPION} / \mathrm{SiO}_{2}$ composite materials from the simultaneous impregnation and decomposition of $\mathrm{Fe}\left(\mathrm{NO}_{3}\right)_{3} .9 \mathrm{H}_{2} \mathrm{O}$ in a mixture of $\mathrm{CO}_{2}$ and ethanol at $523 \mathrm{~K}$ and $25.0 \mathrm{MPa}$. The solubility of the precursor in ethanol $+\mathrm{CO}_{2}$ was also studied. The precursor used is cheap and the reaction conditions are mild, making the process sustainable. Furthermore, the materials obtained are very homogeneous and superparamagnetic.

\section{Materials and methods}

\subsection{Materials}

Tetraethylorthosilicate (TEOS, 99+\%), poly(ethyleneglycol)-block-poly(propylene glycol)block-poly(ethylenegly-col) $(\mathrm{Mw}=5800) \quad(\mathrm{PEO}-\mathrm{PPO}-\mathrm{PEO})$, hexadecyltrimethylammonium bromide $(98+\%)$ or $\mathrm{CTAB}$ and $\left(\mathrm{Fe}\left(\mathrm{NO}_{3}\right)_{3} \cdot 9 \mathrm{H}_{2} \mathrm{O}\right)(99+\%)$ were obtained from Sigma-Aldrich and used as received. $\mathrm{CO}_{2}$ (purity $>99.99 \%$ ) was supplied by Air Liquide. Two different mesoporous $\mathrm{SiO}_{2}$ supports were used: SBA-15 and spherical MCM-41.

Mesoporous silica SBA-15 was prepared following a procedure similar to that described by Zhao et al. $[49,50]$. This material was composed of large micron size particles with an ordered hexagonal cylindrical mesopore distribution. BET surface area and pore size were $730 \mathrm{~m}^{2} / \mathrm{g}$ and $7.2 \mathrm{~nm}$, respectively.

Mesoporous silica MCM-41 nanoparticles were also prepared according to literature procedures[51]. The sample was composed of 50-100 nm spherical particles with hexagonally ordered cylindrical mesopores. BET surface area was $830 \mathrm{~m}^{2} / \mathrm{g}$ for MCM-41. Pore size was 2.3 $\mathrm{nm}$, smaller than that for SBA-15. 


\subsection{View Cell experiments}

The solubility of $\mathrm{Fe}\left(\mathrm{NO}_{3}\right)_{3} \cdot 9 \mathrm{H}_{2} \mathrm{O}$ in the $\mathrm{CO}_{2}+$ ethanol mixture was assessed using a custom made high-pressure variable volume view cell (maximum volume ca. $10 \mathrm{~mL}$ ) following the procedure previously described[44]. Briefly, ca. $50 \mathrm{mg}$ of $\mathrm{Fe}\left(\mathrm{NO}_{3}\right)_{3} \cdot 9 \mathrm{H}_{2} \mathrm{O}$ was dissolved in 3.5-7 mL of ethanol and introduced into the view cell using a syringe. Then the cell was closed and liquid $\mathrm{CO}_{2}$ was introduced into the reactor from a $20 \mathrm{~mL}$ high-pressure sample cylinder by pressure drop. Composition was determined gravimetrically. Mole fraction of $\mathrm{Fe}\left(\mathrm{NO}_{3}\right)_{3} \cdot 9 \mathrm{H}_{2} \mathrm{O}$ in the mixture was kept at 3.3-4.3 x $10^{-4}$ and ethanol content varied between 22 and 34\% mol. The cell was heated up to $333 \mathrm{~K}$ by means of a heating tape connected to a PID controller. Then the sample was compressed by a movable piston to a single phase. Contents of the cell were continuously stirred by a magnetic flea to assure homogeneity. Solubilisation of the solid was established visually. Pressure and temperature conditions were above the bubble points of the system $\mathrm{CO}_{2}+$ ethanol at $333 \mathrm{~K}[52,53]$ in the $\mathrm{CO}_{2}$-expanded liquid region. The solubilisation of the precursor in the reaction mixture is essential in order to achieve the homogeneous impregnation of the $\mathrm{SiO}_{2}$ supports.

\subsection{Composite preparation}

The materials were synthesized using a $100 \mathrm{~mL}$ stirred high-pressure Bolted Closure reactor (Autoclave Eng.). A high pressure syringe pump (ISCO 260D), thermostated at $333 \mathrm{~K}$, was used to introduced $\mathrm{CO}_{2}$ into the reactor. A given amount of the $\mathrm{SiO}_{2}$ support (typically $100 \mathrm{mg}$ ) was placed in contact into the reactor with a volume of $0.18 \%$ mol solution of $\mathrm{Fe}\left(\mathrm{NO}_{3}\right)_{3} \cdot 9 \mathrm{H}_{2} \mathrm{O}$ (between 5 and $20 \mathrm{~mL}$ ) in ethanol. An extra amount of ethanol (up to $20 \mathrm{~mL}$ ) was added in some experiments to reach a concentration $50 \% \mathrm{~mol}$ in ethanol, while keeping constant the metal concentration. The 
reactor was then closed, heated up to $333 \mathrm{~K}$ and filled with $\mathrm{CO}_{2}$ from the syringe pump up to 12.0 MPa.

The mixture was kept at these conditions under constant stirring for 2 hours. The precursor dissolved in the $\mathrm{CO}_{2}+$ ethanol mixture and adsorbed onto the support. Afterwards, the reactor temperature was increased up to $523 \mathrm{~K}$ to produce the insitu decomposition of the precursor. To avoid exceeding the reactor pressure rating (27.0 MPa), a small amount of fluid was vented from the reactor during heating. Materials were kept at these conditions for 2 hours. Then the heater was turn off and the reactor was slowly depressurized. After cooling, the reactor was opened and the dark brown/grey solid material was collected, washed several times with small amounts of ethanol and dried at room temperature. Experiments at $473-500 \mathrm{~K}$ led to weakly magnetic light brown/orange samples. Then the choice of experimental conditions was based on the solubility of the precursor in the $\mathrm{CO}_{2}+$ ethanol mixtures, their magnetic behaviour and the temperature and pressure ratings of the stirred high-pressure reactor $(573 \mathrm{~K}$ and $27.0 \mathrm{MPa})$

For comparative purposes an SBA-15 sample was first impregnated with $\mathrm{Fe}\left(\mathrm{NO}_{3}\right)_{3} \cdot 9 \mathrm{H}_{2} \mathrm{O}$ at 333 $\mathrm{K}$ and $12.0 \mathrm{MPa}$ in the $25 \% \mathrm{~mol}$ ethanol $+\mathrm{CO}_{2}$ solution for 2 hours under stirring and slowly depressurized in 0.5 hours. The sample was then heated in a tubular furnace under $\mathrm{N}_{2}$ or $\mathrm{N}_{2} / \mathrm{H}_{2}$ at $10 \mathrm{~K} / \mathrm{min}$ up to different temperatures $(523,673,773,873$ and $973 \mathrm{~K})$ and kept at these conditions for 1 hour. A reducing atmosphere was employed in an effort to promote formation of the highly magnetic iron oxide phases $\left(\mathrm{Fe}_{3} \mathrm{O}_{4}\right.$ and $\left.\gamma-\mathrm{Fe}_{2} \mathrm{O}_{3}\right)$ and avoid formation of the low magnetic phase $\alpha-\mathrm{Fe}_{2} \mathrm{O}_{3}[16]$. 


\subsection{Materials characterization}

The materials were characterized by Transmission Electron Microscopy (TEM) and X-Ray Diffraction (XRD). Metal content was measured by Energy Dispersive X-ray Spectroscopy (EDX) and Inductively Coupled Plasma Optical Emission Spectroscopy (ICP-OES).

$\mathrm{N}_{2}$ adsorption-desorption experiments of the $\mathrm{SiO}_{2}$ supports at $77 \mathrm{~K}$ were also performed using a Micromeritics ASAP-2020. $\mathrm{SiO}_{2}$ samples were out-gassed at $383 \mathrm{~K}$ for $6 \mathrm{~h}$ before the measurement. The BET equation and the BJH method were used for the specific surface area and pore size distributions calculation[54, 55].

TEM was carried out using a JEOL JEM 2100 electron microscope working at $200 \mathrm{kV}$ equipped with a double tilting Be sample holder $\left( \pm 25^{\circ}\right)$ and EDX (Oxford INCA). Samples were dispersed in 1-butanol over copper grids and dried in air.

Metal loading of all the samples was quantified by ICP-OES. Samples were dissolved in mixtures of $\mathrm{HNO}_{3}$ and HF. Wide angle XRD patterns of the composite materials were collected using a $\mathrm{X}^{\prime}$ PERT MPD diffractometer with $\mathrm{Cu} \mathrm{K} \alpha$ radiation at $2 \theta$ values between 20 and $70^{\circ}$. The Scherrer equation was employed to estimate the crystallite size.

A confocal Raman microscope (NT-MDT Ntegra Spectra) with an excitation source of $532 \mathrm{~nm}$ was used to collect Raman spectra. Samples were focused with an Olympus BXFM microscope equipped with a $50 \mathrm{x}$ objective and were measured in 4 independent points. Spectra were base line corrected, normalized and averaged.

Magnetic measurements were performed using a Superconducting Quantum Interference Device XL-SQUID magnetometer in the temperature range of 4-300 K. Magnetic susceptibility $(\chi)$ was 
measured after cooling the sample at $5 \mathrm{~K}$ in zero-field cooling (ZFC), whereas in the case of fieldcooling measurements (FC), the sample was cooled in the presence of a 500 Oe field down to $5 \mathrm{~K}$. $\chi$ was measured as a function of temperature up to $300 \mathrm{~K}$. Magnetization cycles were also measured at 5 and $250 \mathrm{~K}$, from $-5 \mathrm{~T}$ to $5 \mathrm{~T}$.

\section{Results and discussion}

\subsection{Solubility measurements}

$\mathrm{Fe}\left(\mathrm{NO}_{3}\right)_{3} \cdot 9 \mathrm{H}_{2} \mathrm{O}$ is soluble in mixtures of ethanol $+\mathrm{CO}_{2}$ [43]. Figure 1 shows images of the view cell containing $\mathrm{Fe}\left(\mathrm{NO}_{3}\right)_{3} \cdot 9 \mathrm{H}_{2} \mathrm{O}$ in a 22 and $34 \%$ mol ethanol $+\mathrm{CO}_{2}$ mixtures. $\mathrm{Fe}\left(\mathrm{NO}_{3}\right)_{3} \cdot 9 \mathrm{H}_{2} \mathrm{O}$ mole fraction was 3.3-4.3 x 10-4. At $295 \mathrm{~K}$ and $6 \mathrm{MPa}$ two different phases were clearly observed (Fig. 1b), whilst at $333 \mathrm{~K}$ and $12 \mathrm{MPa}$ (impregnation conditions), the ethanol $+\mathrm{CO}_{2}$ mixtures formed a single fluid phase (Fig. 1a and c). The colour of the solutions turned orange/light brown due to the solubilisation of the Fe salt, although some solid particles were observed at the lower ethanol concentration (Fig. 1a). Increasing the ethanol concentration, the solubility of $\mathrm{Fe}\left(\mathrm{NO}_{3}\right)_{3} \cdot 9 \mathrm{H}_{2} \mathrm{O}$ increased.
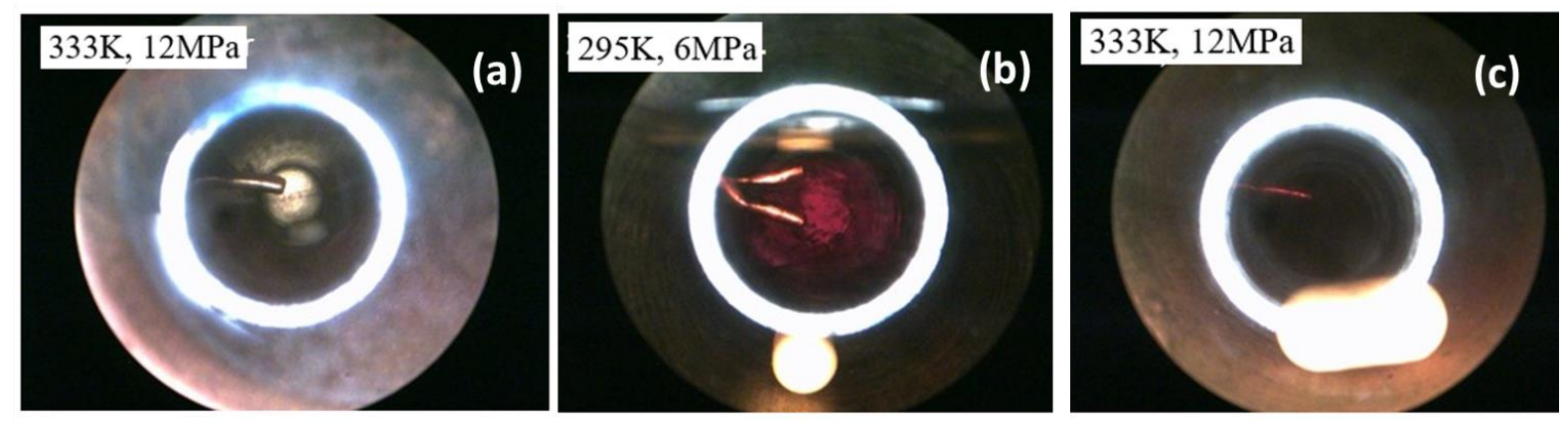

Figure 1. $\mathrm{Fe}\left(\mathrm{NO}_{3}\right)_{3} .9 \mathrm{H}_{2} \mathrm{O}$ in ethanol $+\mathrm{CO}_{2}$ mixtures: (a) $22 \% \mathrm{~mol}$ ethanol and (b and c) $34 \%$ mol ethanol at different pressure and temperature conditions. 


\subsection{Structural characterization}

Samples prepared by the insitu decomposition of $\mathrm{Fe}\left(\mathrm{NO}_{3}\right)_{3} \cdot 9 \mathrm{H}_{2} \mathrm{O}$ in the $\mathrm{CO}_{2}+$ ethanol mixture at $523 \mathrm{~K}$ were dark brown/grey and magnetic. Table 1 summarizes the successful experiments performed and the characteristics of the materials produced.

Table 1. Samples prepared by the insitu decomposition of $\mathrm{Fe}\left(\mathrm{NO}_{3}\right)_{3} \cdot 9 \mathrm{H}_{2} \mathrm{O}$ in $\mathrm{CO}_{2}+$ ethanol at $523 \mathrm{~K}$ and $25 \mathrm{MPa}$.

\begin{tabular}{ccccccc}
\hline Sample \# & $\begin{array}{c}\mathrm{SiO}_{2} \\
\text { support }\end{array}$ & $\begin{array}{c}\% \text { mol } \\
\mathrm{EtOH}\end{array}$ & $\begin{array}{c}\% \text { mass Fe } \\
\text { (ICP) }\end{array}$ & $\begin{array}{c}\% \text { mass } \mathrm{Fe}_{2} \mathrm{O}_{3}{ }^{\mathrm{a}} \\
\text { (ICP) }\end{array}$ & $\begin{array}{c}\mathrm{Size} / \mathrm{nm} \\
(\mathrm{XRD})\end{array}$ & $\begin{array}{c}\mathrm{Size}^{\mathrm{n}} \mathrm{nm}^{\mathrm{b}} \\
(\mathrm{TEM})\end{array}$ \\
\hline 1 & $\mathrm{SBA}-15$ & 25 & $3.7 \pm 0.2$ & 10.6 & 7.5 & 9.3 \\
\hline 2 & $\mathrm{SBA}-15$ & 50 & $6.3 \pm 0.6$ & 18.0 & 7.1 & 6.9 \\
\hline 3 & $\mathrm{MCM}-41$ & 50 & $3.0 \pm 0.5$ & 8.6 & 5.0 & 6.5 \\
\hline
\end{tabular}

a Maximum load 35\% mass $\mathrm{Fe}_{2} \mathrm{O}_{3}$.

${ }^{\mathrm{b}}$ Average from TEM images.

XRD patterns of the different samples prepared insitu in the $\mathrm{CO}_{2}+$ ethanol mixture are compared in Figure 2. XRD patterns fit those of the magnetic phases $\gamma-\mathrm{Fe}_{2} \mathrm{O}_{3}$ and $\mathrm{Fe}_{3} \mathrm{O}_{4}$. (PDF-040755 and 190629, respectively). XRD peaks were quite broad due to the small particle size. Because a $\mathrm{Fe}^{3+}$ precursor was used, we assumed that the phase present was $\gamma-\mathrm{Fe}_{2} \mathrm{O}_{3}$. Particle sizes obtained from the fit of the XRD pattern to the Scherrer equation are given in Table 1. For the samples deposited on SBA-15, the estimated NPs size varied between 7.1-7.5 nm and was very similar to the support pore size $(7.2 \mathrm{~nm})$, which suggested that NPs were deposited into the support pores. However, for the sample deposited on the MCM-41 support (pore size $2.3 \mathrm{~nm}$ ), the particle size evaluated using the Scherrer equation was $5.0 \mathrm{~nm}$. This estimate was much larger than the pore size, which indicated NPs formation outside the mesopores. 
TEM images of the SPION/SBA-15 samples are shown in Figure 3. Images showed clearly the $\mathrm{SiO}_{2}$ mesopores along with the presence of darker nanoparticles corresponding to the metal oxide. Sample 1 prepared using the $25 \%$ mol ethanol $+\mathrm{CO}_{2}$ mixture showed NPs of sizes between $4-15$ $\mathrm{nm}$ (Figure 3a-c). The larger particles seem to be deposited on the external surface of the support. In contrast, sample 2 prepared from the $50 \%$ mol ethanol $+\mathrm{CO}_{2}$ mixture showed smaller NPs, most between 5 and $8 \mathrm{~nm}$ within the support pores, very well dispersed, yielding a very homogeneous material (Figure 3d-f). TEM images proved that the deposition of SPIONs into the SBA-15 mesopores was successful in the ethanol $+\mathrm{CO}_{2}$ mixtures. Metal content by ICP-OES was 3.7 and $6.3 \%$ mass Fe for samples 1 and 2, respectively.

The differences in particle size and NPs dispersion of samples 1 and 2 seem to be related to the different solubility of the precursor in the reaction mixtures. When the $25 \%$ ethanol $+\mathrm{CO}_{2}$ mixture was employed, not all the precursor dissolved in the reaction medium and most NPs deposit on the external surface of the support. However, in the sample prepared using the $50 \%$ ethanol $+\mathrm{CO}_{2}$ mixture, the precursor fully dissolved, favouring deposition of the NPs within the support pores, leading to a larger metal loading. Therefore thanks to the higher solubility of $\mathrm{Fe}\left(\mathrm{NO}_{3}\right)_{3} \cdot 9 \mathrm{H}_{2} \mathrm{O}$ in the $50 \%$ mol ethanol $+\mathrm{CO}_{2}$ mixture, metal oxide deposition was more homogeneous at these conditions and a larger metal content was obtained in sample 2. For this sample, metal incorporation on the support with respect to the amount loaded into the reactor was close to $40 \%$. 


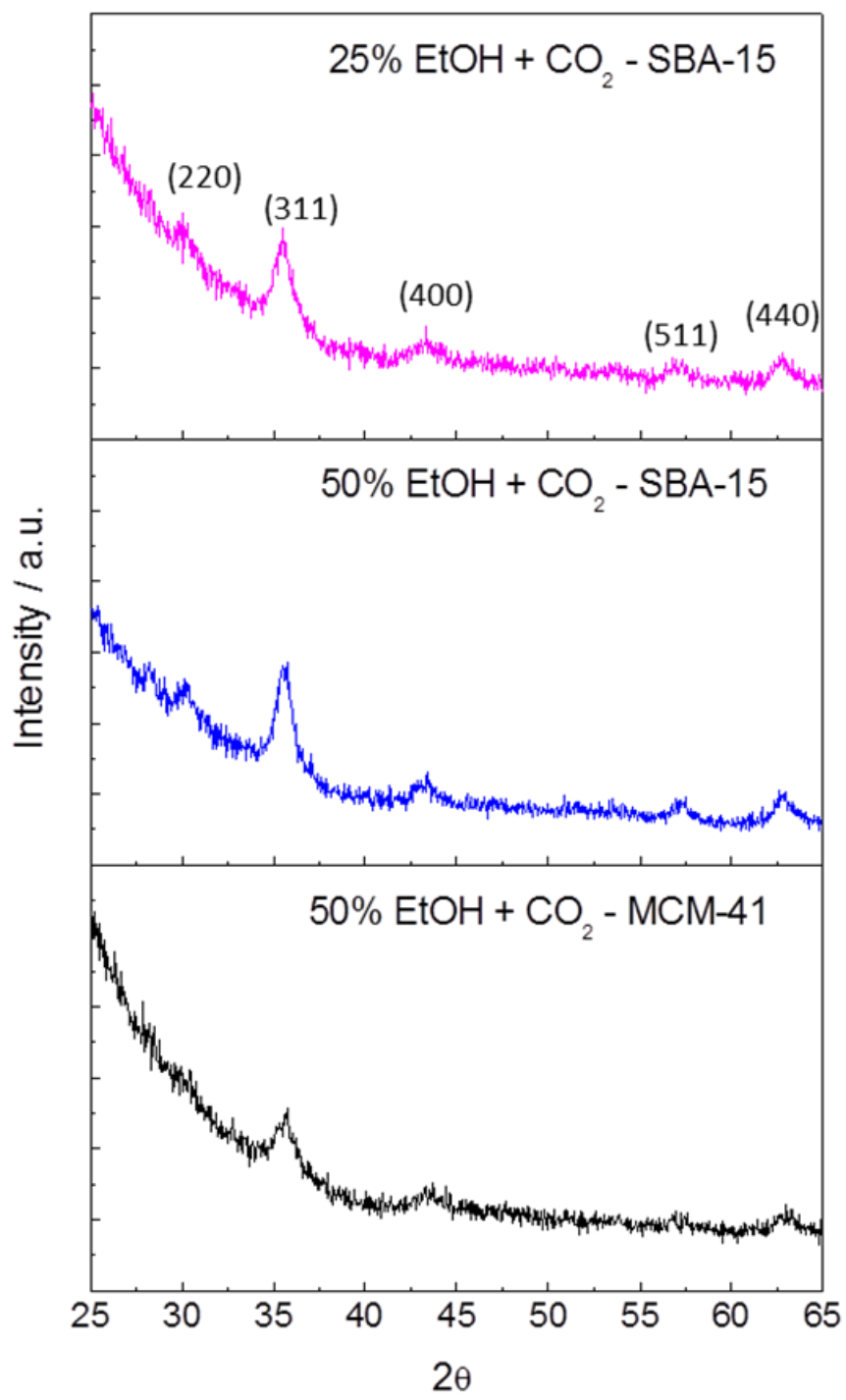

Figure 2- XRD patterns of $\mathrm{SPION} / \mathrm{SiO}_{2}$ samples prepared by the insitu decomposition of $\mathrm{Fe}\left(\mathrm{NO}_{3}\right)_{3} \cdot 9 \mathrm{H}_{2} \mathrm{O}$ at $523 \mathrm{~K}$ on the different supports in the ethanol $+\mathrm{CO}_{2}$ mixtures. 

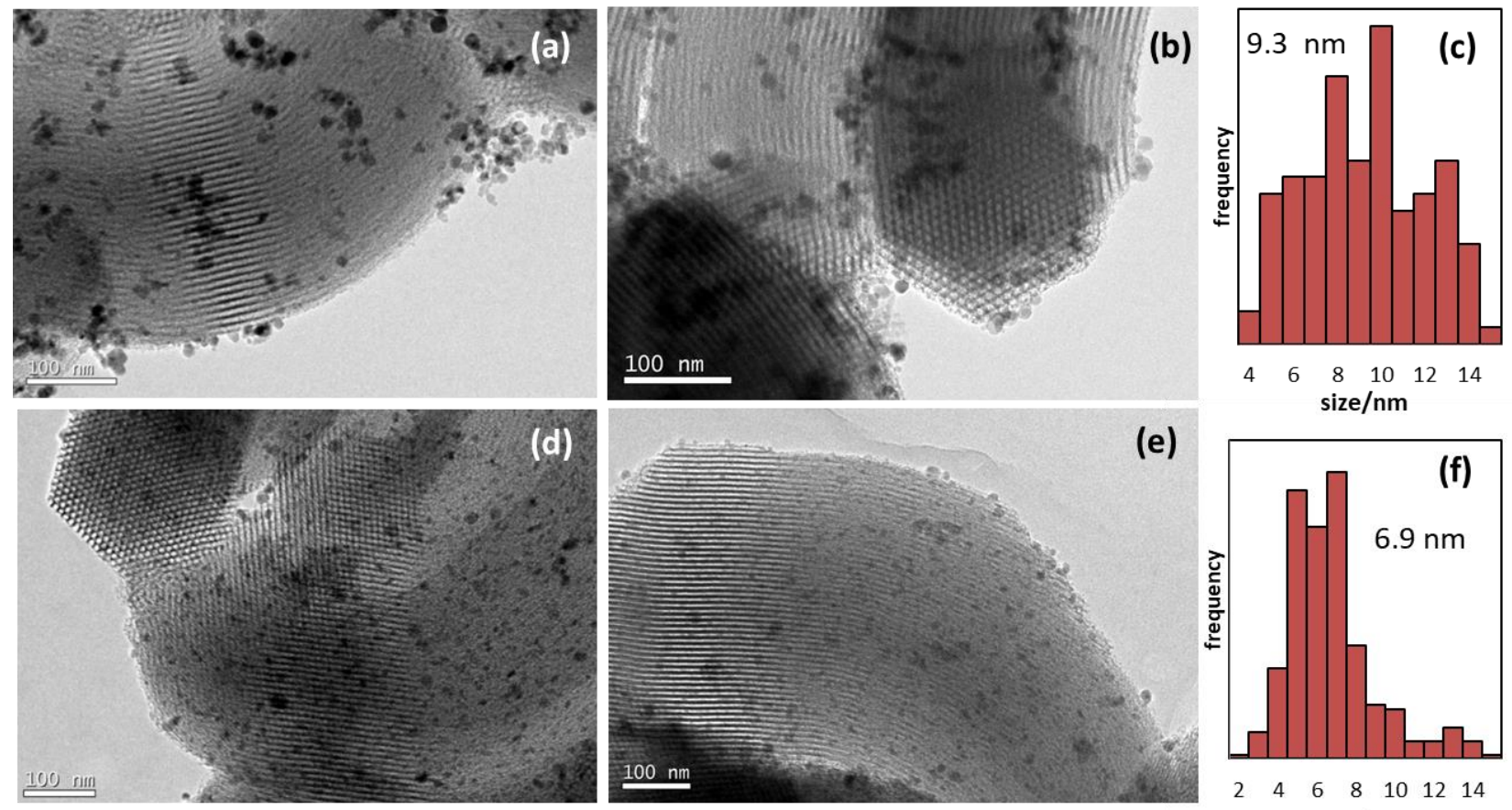

(e)

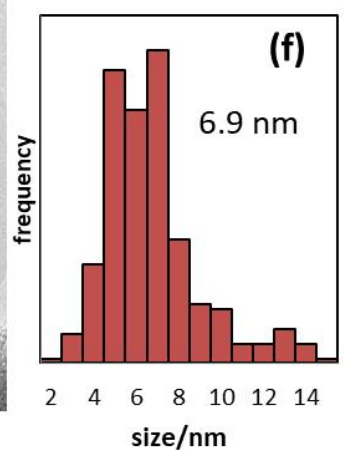

Figure 3- TEM images and particle size distributions of SPION/SBA-15 samples prepared by the insitu decomposition of $\mathrm{Fe}\left(\mathrm{NO}_{3}\right)_{3} \cdot 9 \mathrm{H}_{2} \mathrm{O}$ at $523 \mathrm{~K}$ in $25 \%$ mol ethanol $+\mathrm{CO}_{2}(\mathrm{a}-\mathrm{c})$ and $50 \%$ mol ethanol $+\mathrm{CO}_{2}(\mathrm{~d}-\mathrm{f})$

In view of the previous results, experiments on MCM-41 were only performed using the highest ethanol content. TEM images of the SPION/MCM-41 sample are shown in Figure 4. Images showed small mesoporous $\mathrm{SiO}_{2}$ particles with sizes ranging from 40-100 nm, along with the darker iron oxide NPs of sizes between 3-12 nm (average $6.5 \mathrm{~nm}$ ). NPs seemed to be attached mostly to the external surface of the support and particle size distribution was wide. Particle size controlled is only achieved when NPs deposit into the mesopores. Metal content of this sample by ICP-OES revealed a Fe contents equal to $6.0 \%$ mass, slightly lower than that measured for the SPION/SBA15 sample prepared at the same conditions (sample 2). 
The small pore size of MCM-41 makes difficult the impregnation of the support in the ethanol + $\mathrm{CO}_{2}$ mixture. At the concentrations and conditions of these experiments, the ethanol $+\mathrm{CO}_{2}$ mixture is in the expanded liquid region. Although the reduction in density and viscosity of the mixture and the increased diffusivity of the precursor in this medium in comparison to pure ethanol is high, mass transfer limitations seem to preclude the effectively filling of the small MCM-41 mesopores in the short times used.
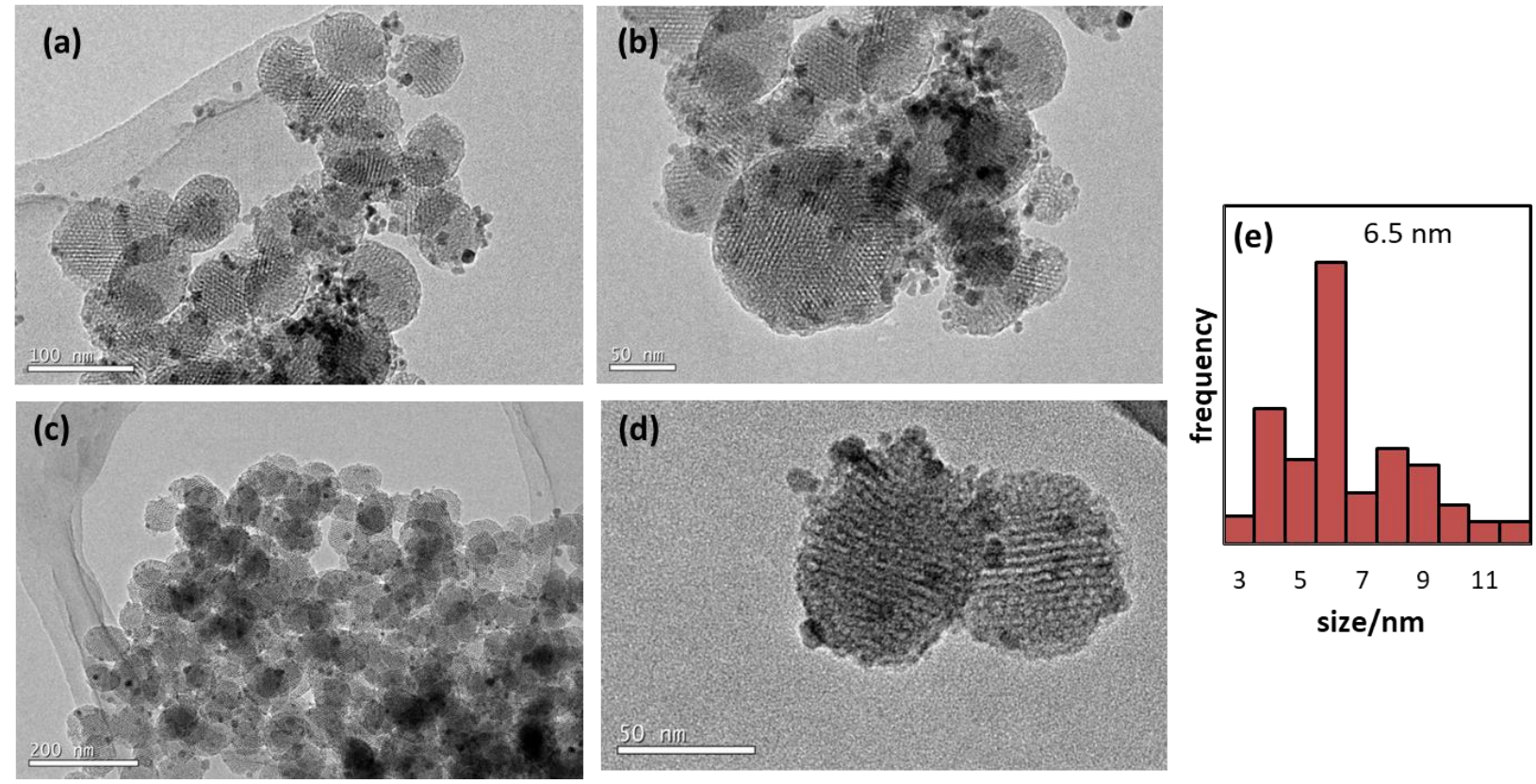

Figure 4- TEM images and particle size distribution of the SPION/MCM-41 sample prepared by the insitu decomposition of $\mathrm{Fe}\left(\mathrm{NO}_{3}\right)_{3} \cdot 9 \mathrm{H}_{2} \mathrm{O}$ at $523 \mathrm{~K}$ in $50 \%$ mol ethanol $+\mathrm{CO}_{2}$ (a-e).

Figure 5 shows XRD patterns of the SPION/SBA-15 samples prepared by the impregnation of $\mathrm{Fe}\left(\mathrm{NO}_{3}\right)_{3} \cdot 9 \mathrm{H}_{2} \mathrm{O}$ in the $25 \% \mathrm{~mol}$ ethanol $+\mathrm{CO}_{2}$ solution at $333 \mathrm{~K}$ and $12.0 \mathrm{MPa}$ and reduced in a tubular furnace at different conditions. When the sample was heated in $\mathrm{N}_{2}$ at $523 \mathrm{~K}$ (temperature used in the insitu experiments), no crystalline phase was observed in the XRD. Furthermore, mixtures of phases including $\mathrm{Fe}$ and $\alpha-\mathrm{Fe}_{2} \mathrm{O}_{3}$ besides $\gamma-\mathrm{Fe}_{2} \mathrm{O}_{3}$ were obtained after decomposition 
in $\mathrm{H}_{2} / \mathrm{N}_{2}$ and $\mathrm{N}_{2}$ at higher temperatures. In order to maximize the presence of the magnetic $\gamma-\mathrm{Fe}_{2} \mathrm{O}_{3}$ phase, impregnated samples were treated in $\mathrm{N}_{2}$ at $973 \mathrm{~K}$. At this temperature a small amount of $\alpha-$ $\mathrm{Fe}_{2} \mathrm{O}_{3}$ was still present. The possible oxidation of $\mathrm{Fe}_{3} \mathrm{O}_{4}$ to $\mathrm{Fe}_{2} \mathrm{O}_{3}$ under exposure of the samples to air cannot be ruled out. XRD peaks were narrower than those obtained for the materials prepared insitu. TEM images of some samples reduced in $\mathrm{N}_{2}$ are provided as supporting information. Iron oxide NPs were larger than those observed in the samples prepared by the insitu decomposition of $\mathrm{Fe}\left(\mathrm{NO}_{3}\right)_{3} \cdot 9 \mathrm{H}_{2} \mathrm{O}$ in $\mathrm{CO}_{2}+$ ethanol at $523 \mathrm{~K}$, which is certainly related to the higher temperatures employed in the thermal treatment and the different decomposition method. Furthermore, particle distribution was also less homogeneous. If the precursor adsorption is not very strong, the precursor may migrate with the solvent during depressurization, leading to an inhomogeneous metal distribution.

Raman spectra of selected samples were also measured. Sample 2 did not give any significant Raman signal probably due to the small iron content and the good metal dispersion within the $\mathrm{SiO}_{2}$ support. Spectrum of the sample impregnated in ethanol $+\mathrm{CO}_{2}$ and heated in $\mathrm{N}_{2}$ at $973 \mathrm{~K}$ confirmed the presence of $\alpha-\mathrm{Fe}_{2} \mathrm{O}_{3}$ and $\gamma-\mathrm{Fe}_{2} \mathrm{O}_{3}$ (see supporting information).

Comparison of the SPION/SBA-15 samples prepared by the insitu decomposition of $\mathrm{Fe}\left(\mathrm{NO}_{3}\right)_{3} \cdot 9 \mathrm{H}_{2} \mathrm{O}$ in ethanol $+\mathrm{CO}_{2}$ with samples previously prepared by wet impregnation of the same precursor in liquid ethanol followed by solvent evaporation and thermal treatment $[16,17]$ revealed that our method allows a much easier control of the oxidation state leading to single phase magnetic materials at much lower temperatures and shorter times in one single step. 


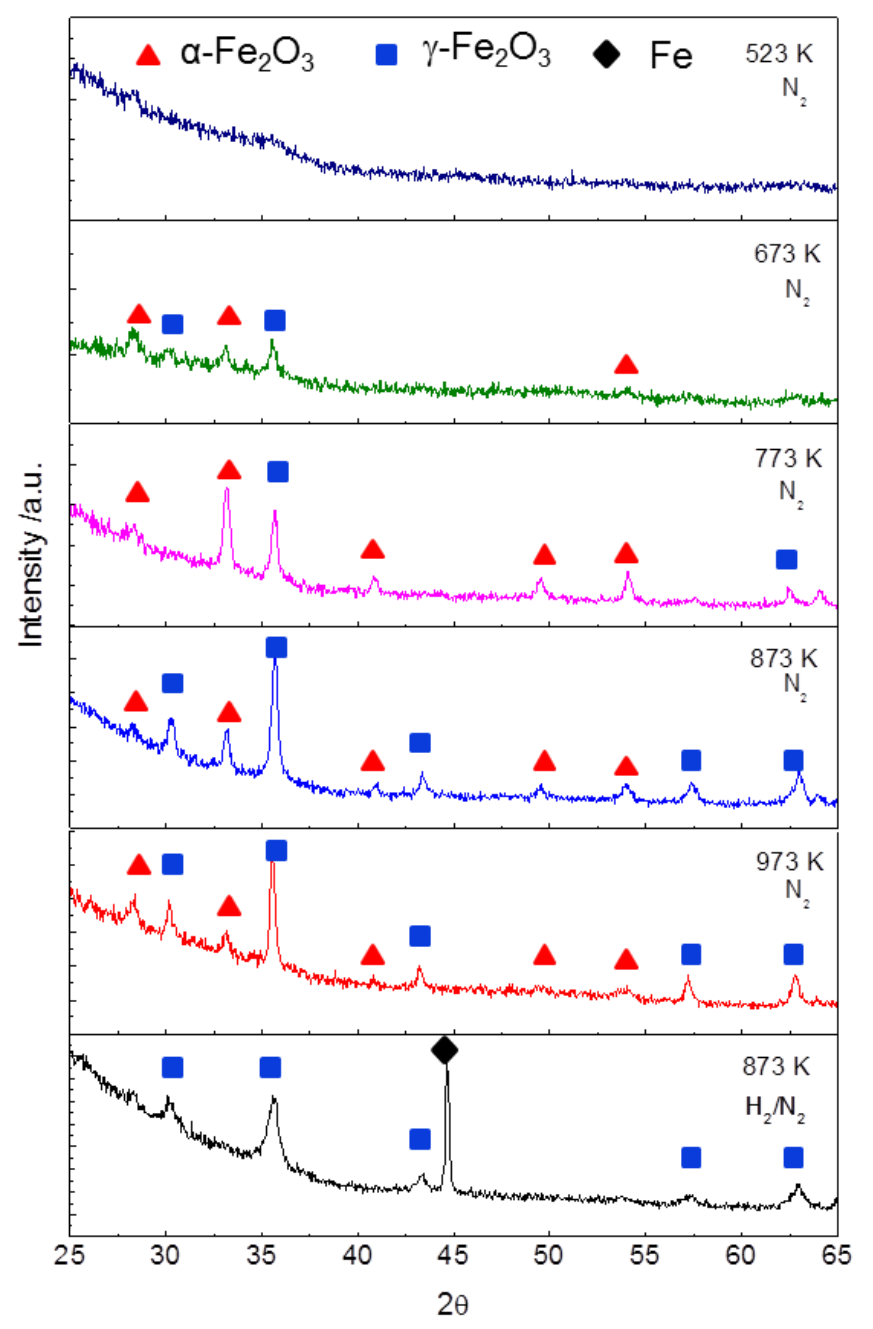

Figure 5- XRD patterns of SPION/SBA-15 samples prepared by impregnation of $\mathrm{Fe}\left(\mathrm{NO}_{3}\right)_{3} \cdot 9 \mathrm{H}_{2} \mathrm{O}$ in a $25 \%$ mol ethanol $+\mathrm{CO}_{2}$ solution and reduced in $\mathrm{N}_{2}$ and $\mathrm{H}_{2} / \mathrm{N}_{2}$ at different temperatures showing the different crystal phases.

\subsection{Reaction mechanism}

The mechanism operating in the deposition of supported nanoparticles by the supercritical fluid reactive deposition (SFRD) technique is well known and it has been recently reviewed [56]. Here we propose a similar mechanism for the reactive deposition of inorganic salts on mesoporous supports using expanded liquid solvents. 
The precursor $\mathrm{Fe}\left(\mathrm{NO}_{3}\right)_{3} \cdot 9 \mathrm{H}_{2} \mathrm{O}$ was dissolved in the ethanol $+\mathrm{CO}_{2}$ mixture at $333 \mathrm{~K}$ and $12.0 \mathrm{MPa}$. This expanded liquid mixture was brought into contact with the mesoporous $\mathrm{SiO}_{2}$ support. The mixture diffused into the support pores and the metal precursor adsorbed on their surface impregnating the support. In contrast to $\mathrm{CO}_{2}$ that adsorbs weakly on $\mathrm{SiO}_{2}$ [57], competitive adsorption of ethanol on the $\mathrm{SiO}_{2}$ surface is possible. Then the temperature was raised to $523 \mathrm{~K}$ in order to promote the insitu decomposition of the precursor in the $\mathrm{CO}_{2}+$ ethanol mixture. At these conditions $\gamma-\mathrm{Fe}_{2} \mathrm{O}_{3} \mathrm{NPs}$ were produced within the $\mathrm{SiO}_{2}$ mesopores. Ming at al. have shown that the decomposition of hydrous metal nitrates in $\mathrm{CO}_{2}$ expanded ethanol proceeds through an intermedium coordinated compound before the corresponding oxide is formed [43]. Then the heater was disconnected and the reactor was vented. When the $50 \%$ ethanol $+\mathrm{CO}_{2}$ mixture was used, the solubility of the precursor was high leading to very homogeneous SPION/SBA-15 materials. In contrast, the precursor solubility in the $25 \%$ ethanol $+\mathrm{CO}_{2}$ mixture was lower and some metal NPs may have deposited directly on the external $\mathrm{SiO}_{2}$ surface from the solid phase.

Because air was not deliberately excluded from the support pores before adding the precursor solution and filling the reactor with $\mathrm{CO}_{2}$, an interphase may have been formed at the initial stages of the filling process. Mass transfer limitations make difficult the filling of the smaller MCM-41 mesopores.

On the other hand, the samples impregnated with $\mathrm{Fe}\left(\mathrm{NO}_{3}\right)_{3} \cdot 9 \mathrm{H}_{2} \mathrm{O}$ in ethanol $+\mathrm{CO}_{2}$ but decomposed after depressurization in the tubular furnace were less homogeneous. If the precursor adsorption is not very strong, the precursor may be transported along with the solvent during depressurization, leading to an inhomogeneous metal distribution. 


\subsection{Magnetic characterization}

Figure 6 shows the temperature dependence of ZFC and FC magnetic susceptibility $(\chi)$ for samples 1-3. Due to the small particle size of the $\gamma-\mathrm{Fe}_{2} \mathrm{O}_{3} \mathrm{NPs}$, the material turned superparamagnetic from the blocking temperature $\left(T_{B}\right)$ to ambient temperature. At temperatures lower than $\mathrm{T}_{\mathrm{B}}$, when the samples were cooled in the presence of a 500 Oe field down to $5 \mathrm{~K}$ (FC), the samples remained magnetized. By contrast, in the ZFC regime $\chi$ decreased with the temperature. The inverse dependence of $\chi$ with temperature in the FC measurements confirmed the ferrimagnetic behaviour of the samples. ZFC and FC curves merged together above $\mathrm{T}_{\mathrm{B}}$ and $\chi$ decreased with temperature due to thermal fluctuations[58]. The higher $\chi$ values were measured for samples 3 and 1, being much smaller for sample 2. The larger particle size of samples 1 and 3 would explain the large $\chi$ values. A similar behaviour is exhibited by nanoparticulated spinel ferrites [59-62]. 

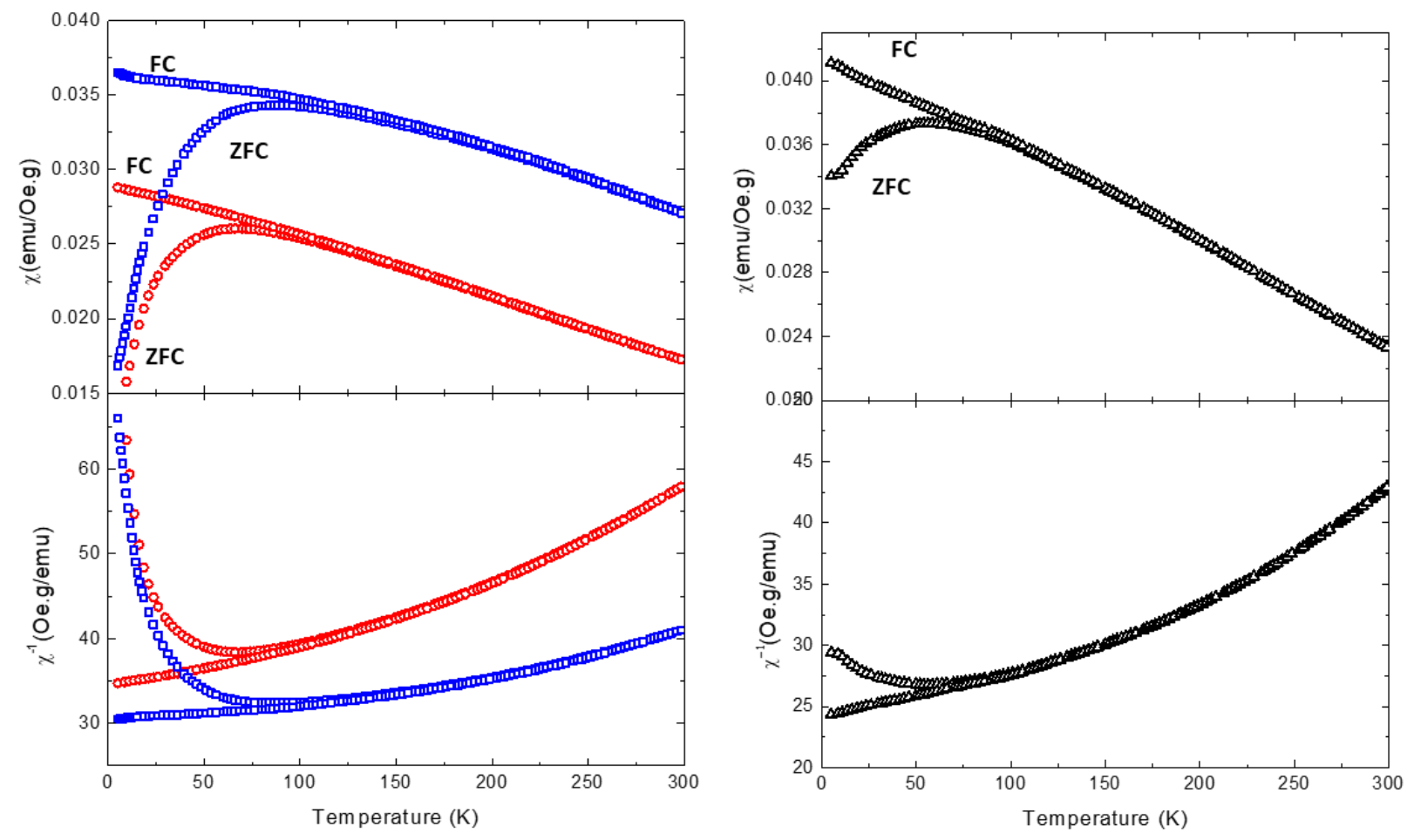

Figure 6- Mass susceptibility measurements up to $300 \mathrm{~K}$ of the $\mathrm{SPION} / \mathrm{SiO}_{2}$ samples: $\square$, sample 1 ; o, sample 2 and $\Delta$, sample 3 .

Magnetization $(\mathrm{M})$ versus magnetic field $(\mathrm{H})$ curves measured at 5 and $250 \mathrm{~K}$ for the different samples are shown in Figure 7. $\mathrm{M}$ increased with $\mathrm{H}$ up to the saturation value $\left(\mathrm{M}_{\mathrm{s}}\right)$. At $250 \mathrm{~K}$, no hysteresis was observed confirming the superparamagnetic nature of the materials. In contrast at $5 \mathrm{~K}$ (below $\mathrm{T}_{\mathrm{B}}$ ) not all the magnetic domains returned to their original orientations at $\mathrm{H}=\mathrm{O}$ and the material exhibited a remnant magnetization $\left(M_{R}\right)$, being necessary to apply a coercive field $\left(H_{c}\right)$ in the opposite direction to reverse the process. Hysteresis loops at $5 \mathrm{~K}$ were characterized by low $\mathrm{M}_{\mathrm{R}}$ and $\mathrm{H}_{\mathrm{R}}$, whist $\mathrm{M}_{\mathrm{s}}$ were high. 

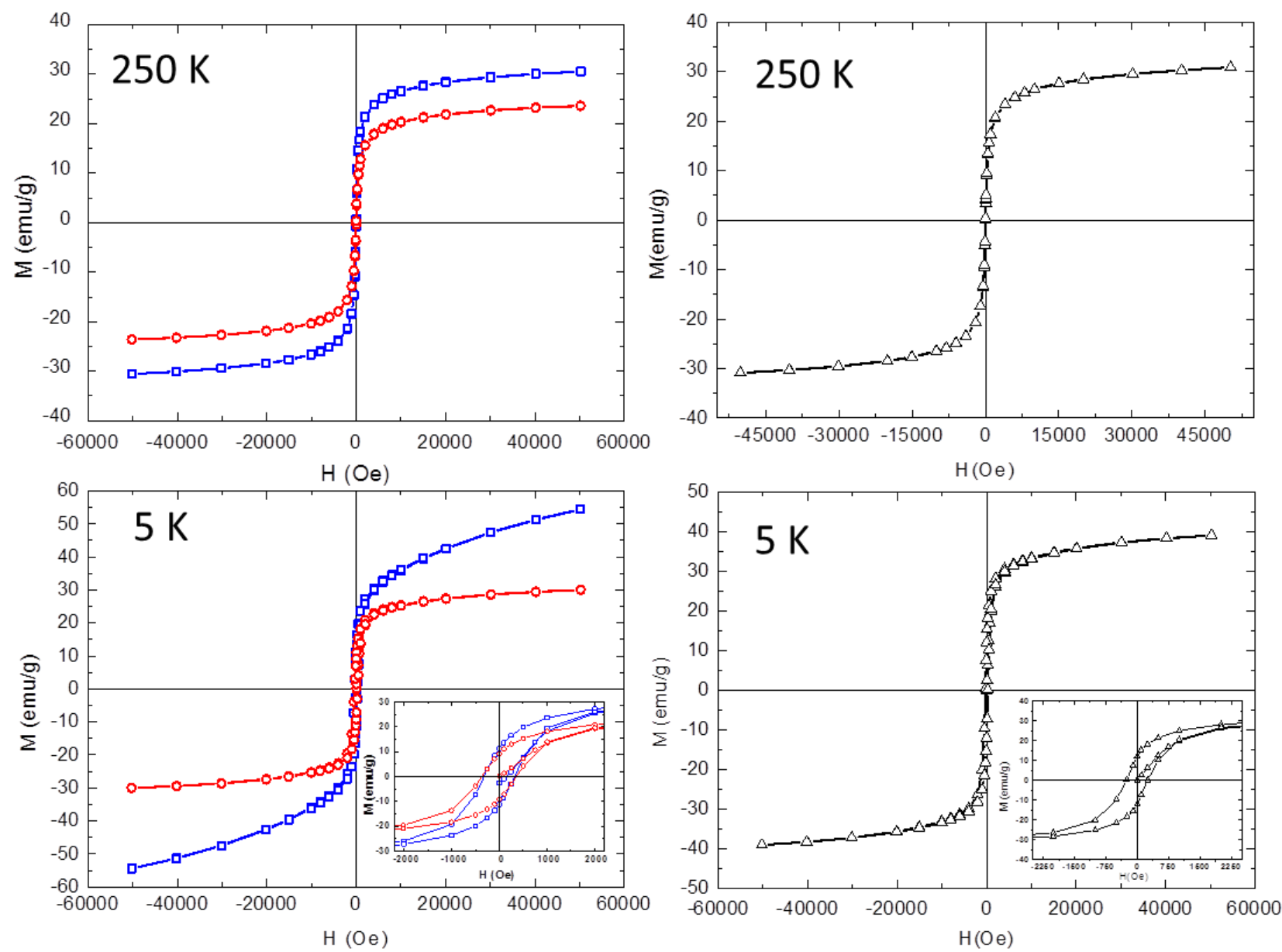

Figure 7- Magnetic susceptibility versus magnetic field curves measurements of the $\mathrm{SPION} / \mathrm{SiO}_{2}$ samples at 5 and $250 \mathrm{~K}: \square$, sample 1; o, sample 2 and $\Delta$, sample 3.

Table 2 shows the values of $M_{s}, M_{R}, H_{c}$ and $T_{B}$ for the different samples. $T_{B}$ was obtained from the maxima of the ZFC measurement versus temperature curve and ranged from 56-91 K. Samples 1 and 2 showed the largest $T_{B}$ values, whilst the smallest $T_{B}$ was obtained for sample $3 . T_{B}$ is directly related to the particle volume. Maxima were relatively narrow for sample 2 in agreement to their particle size distribution. However, the sample deposited on MCM-41 showed a wider 
particle size distribution and the maximum was broader. The smallest value of $\mathrm{T}_{\mathrm{B}}$ obtained for sample 3 could indicate the presence of very small magnetic NPs. These values are similar to those reported for other $\mathrm{SPION} / \mathrm{SiO}_{2}$ composite materials[20].

Table 2. Magnetic parameters for $\mathrm{SPION} / \mathrm{SiO}_{2}$ samples prepared by the insitu decomposition of $\mathrm{Fe}\left(\mathrm{NO}_{3}\right)_{3} \cdot 9 \mathrm{H}_{2} \mathrm{O}$ in ethanol $+\mathrm{CO}_{2}$ at $523 \mathrm{~K}$. Parameters reported per gram of $\gamma-\mathrm{Fe}_{2} \mathrm{O}_{3}$ based on ICP-OES data.

\begin{tabular}{cccccc}
\hline Sample \# & $\begin{array}{c}\mathrm{T}_{\mathrm{B}} \\
(\mathrm{K})\end{array}$ & $\begin{array}{c}\mathrm{H}_{\mathrm{c}, 5 \mathrm{~K}} \\
(\mathrm{Oe})\end{array}$ & $\begin{array}{c}\mathrm{M}_{\mathrm{R}, 5 \mathrm{~K}} \\
(\mathrm{emu} / \mathrm{g})\end{array}$ & $\begin{array}{c}\mathrm{M}_{\mathrm{s}, 5 \mathrm{~K}} \\
(\mathrm{emu} / \mathrm{g})\end{array}$ & $\begin{array}{c}\mathrm{M}_{\mathrm{s}, 250 \mathrm{~K}} \\
(\mathrm{emu} / \mathrm{g})\end{array}$ \\
\hline 1 & 91 & 369 & 11.4 & $>54$ & 31 \\
\hline 2 & 70 & 322 & 9.0 & 30 & 24 \\
\hline 3 & 56 & 250 & 12.5 & 39 & 31 \\
\hline
\end{tabular}

$H_{c}$ and $M_{R}$ at $5 \mathrm{~K}$ were small in all the samples. $M_{s}$ at 5 and $250 \mathrm{~K}$ ranged from 30-55 and 24-31 (emu/g $\mathrm{Fe}_{2} \mathrm{O}_{3}$ ), respectively. As expected, Ms decreased as the temperature increased. At $5 \mathrm{~K}, \mathrm{M}$ values for sample 1 did not reach saturation at the highest $\mathrm{H}$ employed (50k Oe) most likely due to interparticle interactions between the surface layer of canted spins[60]. In sample 2 most of the particles were inside the pores of the matrix and these interactions were minimized. Similarly, the good NP dispersion on the support of sample 3 prevented a strong interparticle interaction. However, NPs at the support surface in sample 1 were agglomerated and interparticle surface interactions increased the surface anisotropy and the hardness of the material as the $\mathrm{M}_{\mathrm{s}}$ values indicate. $\mathrm{M}_{\mathrm{s}, 250 \mathrm{~K}}$ were lower than those reported for bulk $\gamma-\mathrm{Fe}_{2} \mathrm{O}_{3}(76 \mathrm{emu} / \mathrm{g})$ [58] related to the small particle size and the presence of magnetic anisotropy at the particle surface. These values 
were however larger than those previously reported for similar $\gamma-\mathrm{Fe}_{2} \mathrm{O}_{3} / \mathrm{SBA}-15$ materials[20] but slightly lower than the values reported by Yiu et al. for $\mathrm{Fe}_{3} \mathrm{O}_{4} / \mathrm{SBA}-15$ materials[16] .

\section{Conclusions}

$\mathrm{SPION} / \mathrm{SiO}_{2}$ materials were prepared by the impregnation and insitu decomposition of $\mathrm{Fe}\left(\mathrm{NO}_{3}\right)_{3} \cdot 9 \mathrm{H}_{2} \mathrm{O}$ into mesoporous $\mathrm{SiO}_{2}$ supports at $523 \mathrm{~K}$ and $25.0 \mathrm{MPa}$ using ethanol $+\mathrm{CO}_{2}$ mixtures. Ethanol was required to solubilize the salt in $\mathrm{CO}_{2}$ and helped in the decomposition process. At the concentrations and impregnation conditions of these experiments, the ethanol + $\mathrm{CO}_{2}$ mixture was in the expanded liquid region. The method was simple and allowed the preparation of the composite materials in one step using $\mathrm{CO}_{2}$ as solvent and reaction medium. $\gamma$ $\mathrm{Fe}_{2} \mathrm{O}_{3}$ nanoparticles of average size between 6-9 nm were deposited on the $\mathrm{SiO}_{2}$ supports with loadings up to $18.0 \%$ mass. In the $50 \%$ ethanol $+\mathrm{CO}_{2}$ mixture, $\gamma-\mathrm{Fe}_{2} \mathrm{O}_{3} \mathrm{NPs}$ deposited into the support pores of SBA-15 but mostly on the external surface of MCM-41. Materials were very homogeneous due to the large solubility of the precursor in the ethanol $+\mathrm{CO}_{2}$ mixture. Mass transfer limitations seemed to preclude the effectively filling of the small MCM-41 mesopores in the short times used. The very small $\mathrm{T}_{\mathrm{B}}$ obtained for the MCM-41 sample, however, suggest the presence of very small magnetic NPs. Larger impregnation times and/or higher impregnation temperatures may be required to promote extensive deposition into the smaller mesopores.

Composite materials were superparamagnetic at room temperature with $\mathrm{T}_{\mathrm{B}}$ below $91 \mathrm{~K}$ for all the samples. Hysteresis loops at $5 \mathrm{~K}$ were small with high $\mathrm{Ms}$ and low $\mathrm{H}_{\mathrm{R}}$. The materials prepared have many potential technological applications. 


\section{Acknowledgements}

We acknowledge financial support from the Spanish Ministry of Science and Innovation, research projects MAT2017-84385-R and RTI2018-097230-B-I00 and from UCM-Santander, research project PR75/18-21583. We thank the Centres of Scientific Instrumentation at UCM (X-ray diffraction, Physical techniques, Geological Techniques and ICTS National Microscopy Centre) and their staff, for use of the technical facilities.

\section{Appendix A. Supplementary data}

TEM images of SPION/SBA-15 samples obtained by the impregnation of $\mathrm{Fe}\left(\mathrm{NO}_{3}\right)_{3} \cdot 9 \mathrm{H}_{2} \mathrm{O}$ in ethanol $+\mathrm{CO}_{2}$ and further decomposed in $\mathrm{N}_{2}$ (Figure $\mathrm{S} 1$ ).

Raman spectrum of a $\mathrm{SiO}_{2}$ support impregnated with $\mathrm{Fe}\left(\mathrm{NO}_{3}\right)_{3} \cdot 9 \mathrm{H}_{2} \mathrm{O}$ in ethanol $+\mathrm{CO}_{2}$ and heated in $\mathrm{N}_{2}$ at $973 \mathrm{~K}$ (Figure $\left.\mathrm{S} 2\right)$.

\section{References}

[1] M.D. Marquez-Medina, P. Prinsen, H.K. Li, K.M. Shih, A.A. Romero, R. Luque, Continuous-Flow Synthesis of Supported Magnetic Iron Oxide Nanoparticles for Efficient Isoeugenol Conversion into Vanillin, ChemSusChem, 11 (2018) 389-396.

[2] L.M. Rossi, N.J.S. Costa, F.P. Silva, R. Wojcieszak, Magnetic nanomaterials in catalysis: advanced catalysts for magnetic separation and beyond, Green Chem., 16 (2014) 2906-2933.

[3] B. Duong, H. Khurshid, P. Gangopadhyay, J. Devkota, K. Stojak, H. Srikanth, L. Tetard, R.A. Norwood, N. Peyghambarian, M.H. Phan, J. Thomas, Enhanced Magnetism in Highly Ordered Magnetite Nanoparticle-Filled Nanohole Arrays, Small, 10 (2014) 2840-2848. 
[4] R. Kaur, A. Hasan, N. Iqbal, S. Alam, M.K. Saini, S.K. Raza, Synthesis and surface engineering of magnetic nanoparticles for environmental cleanup and pesticide residue analysis: A review, J. Sep. Sci., 37 (2014) 1805-1825.

[5] B. Julian-Lopez, C. Boissiere, C. Chaneac, D. Grosso, S. Vasseur, S. Miraux, E. Duguet, C. Sanchez, Mesoporous maghemite-organosilica microspheres: a promising route towards multifunctional platforms for smart diagnosis and therapy, J. Mater. Chem., 17 (2007) 1563-1569.

[6] Q.A. Pankhurst, J. Connolly, S.K. Jones, J. Dobson, Applications of magnetic nanoparticles in biomedicine, Journal of Physics D-Applied Physics, 36 (2003) R167R181.

[7] J. Liu, S.Z. Qiao, Q.H. Hu, G.Q. Lu, Magnetic Nanocomposites with Mesoporous Structures: Synthesis and Applications, Small, 7 (2011) 425-443.

[8] M. Manzano, M. Vallet-Regí, Mesoporous silica nanoparticles in nanomedicine applications, J. Mater. Sci. Mater. Med., 29 (2018) 65.

[9] H. Atashin, R. Malakooti, Magnetic iron oxide nanoparticles embedded in SBA-15 silica wall as a green and recoverable catalyst for the oxidation of alcohols and sulfides, J. Saudi Chem. Soc., 21 (2017) S17-S24.

[10] F. Rajabi, T. Kakeshpour, M.R. Saidi, Supported iron oxide nanoparticles: Recoverable and efficient catalyst for oxidative S-S coupling of thiols to disulfides, Catal. Commun., 40 (2013) 13-17.

[11] S. Egodawatte, A. Datt, E.A. Burns, S.C. Larsen, Chemical Insight into the Adsorption of Chromium(III) on Iron Oxide/Mesoporous Silica Nanocomposites, Langmuir, 31 (2015) 7553-7562.

[12] E. Guisasola, L. Asín, L. Beola, J.M. de la Fuente, A. Baeza, M. Vallet-Regí, Beyond Traditional Hyperthermia: In Vivo Cancer Treatment with Magnetic-Responsive Mesoporous Silica Nanocarriers, ACS Appl. Mater. Interfaces, 10 (2018) 12518-12525. 
[13] A. Baeza, E. Guisasola, E. Ruiz-Hernández, M. Vallet-Regí, Magnetically Triggered Multidrug Release by Hybrid Mesoporous Silica Nanoparticles, Chem. Mater., 24 (2012) 517-524.

[14] N.I. Cuello, V.R. Elias, C.E.R. Torres, M.E. Crivello, M.I. Oliva, G.A. Eimer, Development of iron modified MCM-41 as promising nano-composites with specific magnetic behavior, Microporous Mesoporous Mater., 203 (2015) 106-115.

[15] A. Zelenakova, V. Zelenak, J. Bednarcik, P. Hrubovcak, J. Kovac, Magnetic nanocomposites of periodic mesoporous silica: The influence of the silica substrate dimensionality on the inter-particle magnetic interactions, J. Alloy Compd., 582 (2014) 483-490.

[16] H.H.P. Yiu, M.A. Keane, Z.A.D. Lethbridge, M.R. Lees, A.J. El Haj, J. Dobson, Synthesis of novel magnetic iron metal-silica (Fe-SBA-15) and magnetite-silica (Fe3O4SBA-15) nanocomposites with a high iron content using temperature-programed reduction, Nanotechnology, 19 (2008).

[17] H.H.P. Yiu, S.C. McBain, A.J. El Haj, J. Dobson, A triple-layer design for polyethyleneimine-coated, nanostructured magnetic particles and their use in DNA binding and transfection, Nanotechnology, 18 (2007).

[18] P. Munnik, P.E. de Jongh, K.P. de Jong, Recent Developments in the Synthesis of Supported Catalysts, Chem. Rev., 115 (2015) 6687-6718.

[19] G. Collins, K. Rahme, J. O'Connell, J.D. Holmes, Embedding colloidal nanoparticles inside mesoporous silica using gas expanded liquids for high loading recyclable catalysts, Catal. Sci. Technol., 6 (2016) 7212-7219.

[20] H.A. Lin, C.H. Liu, W.C. Huang, S.C. Lion, M.W. Chu, C.H. Chen, J.F. Lee, C.M. Yang, Novel Magnetically Separable Mesoporous Fe2O3@SBA-15 Nanocomposite with Fully Open Mesochannels for Protein Immobilization, Chem. Mater., 20 (2008) 6617-6622. 
[21] E. Delahaye, V. Escax, N. El Hassan, A. Davidson, R. Aquino, V. Dupuis, R. Perzynski, Y.L. Raikher, "Nanocasting": Using SBA-15 silicas as hard templates to obtain ultrasmall monodispersed gamma-Fe2O3 nanoparticles, J. Phys. Chem. B, 110 (2006) 26001-26011.

[22] R.G. Digigow, J.-F. Dechezelles, H. Dietsch, I. Geissbuehler, D. Vanhecke, C. Geers, A.M. Hirt, B. Rothen-Rutishauser, A. Petri-Fink, Preparation and characterization of functional silica hybrid magnetic nanoparticles, J. Magn. Magn. Mater., 362 (2014) 72-79.

[23] P. Fabrizioli, T. Burgi, M. Burgener, S. van Doorslaer, A. Baiker, Synthesis, structural and chemical properties of iron oxide-silica aerogels, J. Mater. Chem., 12 (2002) 619-630.

[24] D. Niznansky, N. Viart, J.L. Rehspringer, Nanocomposites Fe2O3/SiO2-preparation by sol-gel method and physical properties, J. Sol-Gel Sci. Technol., 8 (1997) 615-618.

[25] D. Niznansky, J.L. Rehspringer, M. Drillon, Preparation of magentic nanoaprtilces (gamma-Fe2O3) in the silica matrix, IEEE Trans. Magn., 30 (1994) 821-823.

[26] C.A. Garcia-Gonzalez, E. Carenza, M.L. Zeng, I. Smirnova, A. Roig, Design of biocompatible magnetic pectin aerogel monoliths and microspheres, RSC Advances, 2 (2012) 9816-9823.

[27] E. Taboada, R. Solanas, E. Rodriguez, R. Weissleder, A. Roig, Supercritical-FluidAssisted One-Pot Synthesis of Biocompatible Core(gamma-Fe2O3)/Shell(SiO2) Nanoparticles as High Relaxivity T-2-Contrast Agents for Magnetic Resonance Imaging, Adv. Funct. Mater., 19 (2009) 2319-2324.

[28] C. Aymonier, A. Loppinet-Serani, H. Reverón, Y. Garrabos, F. Cansell, Review of supercritical fluids in inorganic materials science, J. Supercrit. Fluids, 38 (2006) 242-251.

[29] A.M. López-Periago, C. Domingo, Features of supercritical CO2 in the delicate world of the nanopores, J. Supercrit. Fluids, 134 (2018) 204-213. 
[30] A. Castro, J. Morere, A. Cabañas, L.P. Ferreira, M. Godinho, P. Ferreira, P.M. Vilarinho, Designing nanocomposites using supercritical $\mathrm{CO} 2$ to insert Ni nanoparticles into the pores of nanopatterned BaTiO3 thin films, J. Mater. Chem. C, 5 (2017) 1083-1089.

[31] E. Sanchez-Miguel, M.J. Tenorio, J. Morere, A. Cabañas, Green preparation of PtRu and PtCu/SBA-15 catalysts using supercritical CO2, J. CO2 Util., 22 (2017) 382-391.

[32] Y. Sanchez-Vicente, L.A. Stevens, C. Pando, M. Jose Torralvo, C.E. Snape, T.C. Drage, A. Cabañas, A new sustainable route in supercritical $\mathrm{CO} 2$ to functionalize silica SBA-15 with 3-aminopropyltrimethoxysilane as material for carbon capture, Chem. Eng. J., 264 (2015) 886-898.

[33] https://webbook.nist.gov/, in.

[34] U.T. Lam, R. Mammucari, K. Suzuki, N.R. Foster, Processing of iron oxide nanoparticles by supercritical fluids, Ind. Eng. Chem. Res., 47 (2008) 599-614.

[35] A. Cabañas, M. Poliakoff, The continuous hydrothermal synthesis of nano-particulate ferrites in near critical and supercritical water, J. Mater. Chem., 11 (2001) 1408-1416.

[36] A.S. Teja, P.Y. Koh, Synthesis, properties, and applications of magnetic iron oxide nanoparticles, Prog. Cryst. Growth. Ch., 55 (2009) 22-45.

[37] Y.L. Hao, A.S. Teja, Continuous hydrothermal crystallization of alpha-Fe2O3 and Co3O4 nanoparticles, J. Mater. Res., 18 (2003) 415-422.

[38] O. Pascu, S. Marre, C. Aymonier, A. Roig, Ultrafast and continuous synthesis of crystalline ferrite nanoparticles in supercritical ethanol, Nanoscale, 5 (2013) 2126-2132.

[39] B. Veriansyah, J.D. Kim, B.K. Min, J. Kim, Continuous synthesis of magnetite nanoparticles in supercritical methanol, Mater. Lett., 64 (2010) 2197-2200. 
[40] X.T. Liu, S.N. Jiang, M.J. Niu, S.M. Li, W.X. Li, S.S. Yu, Synthesis and Magnetic Properties of Ferroferric Oxide in Supercritical Methanol, J. Nanosci. Nanotechnol.,, 19 (2019) 833-838.

[41] T.A. Crowley, K.J. Ziegler, D.M. Lyons, D. Erts, H. Olin, M.A. Morris, J.D. Holmes, Synthesis of metal and metal oxide nanowire and nanotube arrays within a mesoporous silica template, Chem. Mater., 15 (2003) 3518-3522.

[42] F.Y. Cao, C.L. Chen, Q. Wang, Q.W. Chen, Synthesis of carbon-Fe3O4 coaxial nanofibres by pyrolysis of ferrocene in supercritical carbon dioxide, Carbon, 45 (2007) 727-731.

[43] J. Ming, C. Wu, H. Cheng, Y. Yu, F. Zhao, Reaction of hydrous inorganic metal salts in $\mathrm{CO} 2$ expanded ethanol: Fabrication of nanostructured materials via supercritical technology, J. Supercrit. Fluids, 57 (2011) 137-142.

[44] M.J. Tenorio, S. Ginés, C. Pando, J.A.R. Renuncio, A. Cabañas, Solubility of the Metal Precursor Ni(NO3)2 $6 \mathrm{H} 2 \mathrm{O}$ in High-Pressure CO2 + Ethanol Mixtures, J. Chem. Eng. Data, 63 (2018) 1065-1071.

[45] Z. Sun, H. Yuan, Z. Liu, B. Han, X. Zhang, A Highly Efficient Chemical Sensor Material for H2S: $\alpha$-Fe2O3 Nanotubes Fabricated Using Carbon Nanotube Templates, Adv. Mater., 17 (2005) 2993-2997.

[46] X. Hu, M. Ma, M. Zeng, Y. Sun, L. Chen, Y. Xue, T. Zhang, X. Ai, R.G. Mendes, M.H. Rümmeli, L. Fu, Supercritical Carbon Dioxide Anchored Fe3O4 Nanoparticles on Graphene Foam and Lithium Battery Performance, ACS Appl. Mater. Interfaces, 6 (2014) 22527-22533.

[47] L.Y. Wang, L.H. Zhuo, C. Zhang, F.Y. Zhao, Supercritical Carbon Dioxide Assisted Deposition of Fe3O4 Nanoparticles on Hierarchical Porous Carbon and Their LithiumStorage Performance, Chem.: Eur. J., 20 (2014) 4308-4315. 
[48] L. Wang, L. Zhuo, F. Zhao, Carbon dioxide-expanded ethanol-assisted synthesis of carbon-based metal composites and their catalytic and electrochemical performance in lithium-ion batteries, Chinese J. Catal., 37 (2016) 218-226.

[49] D.Y. Zhao, J.L. Feng, Q.S. Huo, N. Melosh, G.H. Fredrickson, B.F. Chmelka, G.D. Stucky, Triblock copolymer syntheses of mesoporous silica with periodic 50 to 300 angstrom pores, Science, 279 (1998) 548-552.

[50] D.Y. Zhao, Q.S. Huo, J.L. Feng, B.F. Chmelka, G.D. Stucky, Nonionic triblock and star diblock copolymer and oligomeric surfactant syntheses of highly ordered, hydrothermally stable, mesoporous silica structures, J. Am. Chem. Soc., 120 (1998) 60246036.

[51] H. Chen, J. He, Fine control over the morphology and structure of mesoporous silica nanomaterials by a dual-templating approach, Chem. Comm., (2008) 4422-4424.

[52] Ž. Knez, M. Škerget, L. Ilič, C. Lütge, Vapor-liquid equilibrium of binary CO2organic solvent systems (ethanol, tetrahydrofuran, ortho-xylene, meta-xylene, paraxylene), J. Supercrit. Fluids,, 43 (2008) 383-389.

[53] C. Secuianu, V. Feroiu, D. Geană, Phase behavior for carbon dioxide+ethanol system: Experimental measurements and modeling with a cubic equation of state, J. Supercrit. Fluids, 47 (2008) 109-116.

[54] M. Jaroniec, M. Kruk, J.P. Olivier, Standard Nitrogen Adsorption Data for Characterization of Nanoporous Silicas, Langmuir, 15 (1999) 5410-5413.

[55] E. Barret, L.G. Joyner, P.P. Halenda, The determination of pore volume and area distributions in porous substances. I. Computations for nitrogen isotherms, J. Am. Chem. Soc., 73 (1951) 373-380.

[56] M. Türk, C. Erkey, Synthesis of supported nanoparticles in supercritical fluids by supercritical fluid reactive deposition: Current state, further perspectives and needs, J. Supercrit Fluids, 134 (2018) 176-183. 
[57] S. Reiser, M. Türk, Influence of temperature and high-pressure on the adsorption behavior of scCO2 on MCM-41 and SBA-15, J. Supercrit. Fluids, 144 (2019) 122-133.

[58] B.D. Cullity, C.D. Graham, Introduction to Magnetic Materials, 2nd ed., Wiley, Cambridge, 1972.

[59] V. Blanco-Gutierrez, R. Saez-Puche, M.J. Torralvo-Fernandez, Superparamagnetism and interparticle interactions in $\mathrm{ZnFe} 2 \mathrm{O} 4$ nanocrystals, J. Mater. Chem., 22 (2012) 29923003 .

[60] V. Blanco-Gutierrez, M. Virumbrales, R. Saez-Puche, M.J. Torralvo-Fernandez, Superparamagnetic Behavior of MFe2O4 Nanoparticles and MFe2O4/SiO2 Composites (M: Co, Ni), J. Phys. Chem. C, 117 (2013) 20927-20935.

[61] M. Virumbrales, R. Saez-Puche, V. Blanco-Gutierrez, M.J. Torralvo-Fernandez, Discussion on the Interparticle Interactions in $\mathrm{NiFe} 2 \mathrm{O} 4$ and $\mathrm{ZnFe} 2 \mathrm{O} 4$ Nanosized Systems Based on the Matrix Effects in the Magnetic Behavior, J. Phys. Chem. Cb, 121 (2017) 4029-4036.

[62] M. Virumbrales, R. Saez-Puche, M. Jose Torralvo, V. Blanco-Gutierrez, Mesoporous Silica Matrix as a Tool for Minimizing Dipolar Interactions in NiFe2O4 and ZnFe2O4 Nanoparticles, Nanomaterials, 7 (2017). 


\section{Supplementary Material}

\section{One-step Sustainable Preparation of Superparamagnetic}

\section{Iron Oxide Nanoparticles Supported on Mesoporous $\mathrm{SiO}_{2}$}

Elena Chamorro, ${ }^{a}$ M. José Tenorio, ${ }^{b, \dagger}$ Lourdes Calvo, ${ }^{a}$ M. José Torralvo, ${ }^{c}$ Regino Sáez-Puche $e^{c}$ and Albertina Cabañas ${ }^{b}$

${ }^{a}$ Dep. Chemical Engineering, ${ }^{b}$ Dep. Physical Chemistry, ${ }^{c}$ Dep. Inorganic Chemistry, Universidad Complutense de Madrid, Avda. Complutense s/n, 28040 Madrid, Spain

†Current address: Chemical, Energy and Mechanical Technology Dep, Universidad Rey Juan Carlos, c/Tulipán s/n, 28933 Móstoles, Madrid, Spain

* Corresponding author: Albertina Cabañas, e-mail: a.cabanas@quim.ucm.es

TEM images of the SPION/S samples obtained by impregnation of the SBA-15 support using $\mathrm{Fe}\left(\mathrm{NO}_{3}\right)_{3} \cdot 9 \mathrm{H}_{2} \mathrm{O}$ in ethanol $+\mathrm{CO}_{2}$ mixtures at $333 \mathrm{~K}$ and $12.0 \mathrm{MPa}$ and further decomposed in a tubular furnace in $\mathrm{N}_{2}$ are shown in Figure S1. Iron oxide nanoparticles (NPs) are larger than those observed in the samples prepared by insitu decomposition of $\mathrm{Fe}\left(\mathrm{NO}_{3}\right)_{3} \cdot 9 \mathrm{H}_{2} \mathrm{O}$ in $\mathrm{CO}_{2}$-expanded ethanol at $523 \mathrm{~K}$ (Figure 3 of the manuscript). Furthermore, NP distribution is also less homogeneous. If the precursor adsorption to the support is not very strong, the precursor may be transported along with the solvent during depressurization, leading to an inhomogeneous metal distribution. 


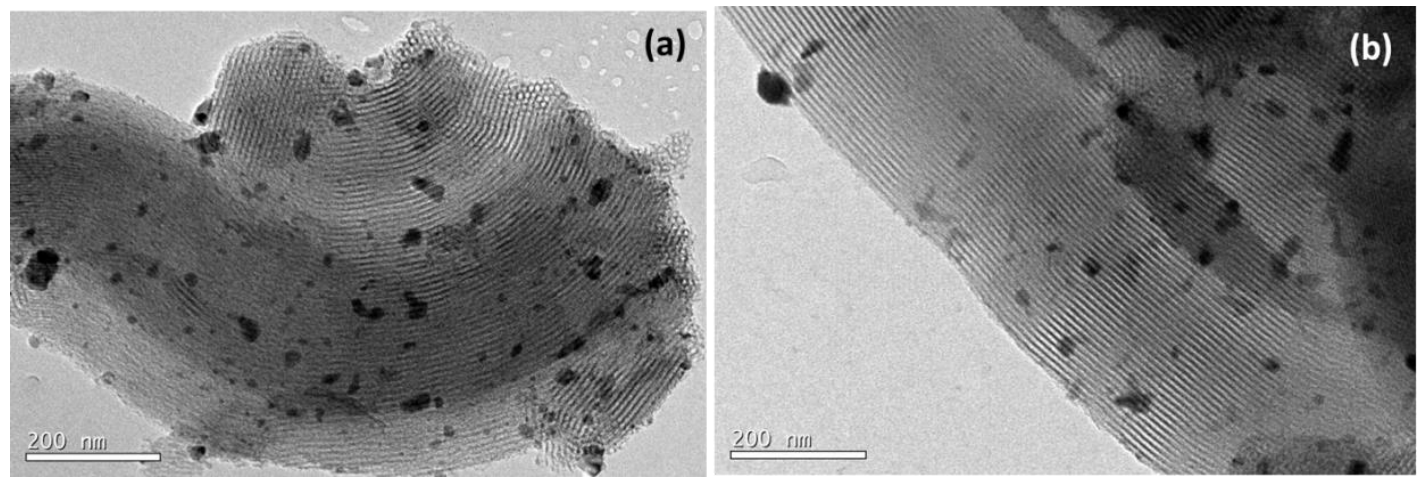

Figure S1- TEM of iron oxide/SBA-15 samples prepared by impregnation of the support with $\mathrm{Fe}\left(\mathrm{NO}_{3}\right)_{3} \cdot 9 \mathrm{H}_{2} \mathrm{O}$ in $\mathrm{CO}_{2}$-expanded ethanol at $333 \mathrm{~K}$ and $12.0 \mathrm{MPa}$ : (a) $25 \% \mathrm{~mol}$ ethanol $+\mathrm{CO}_{2}$ mixture, heated in $\mathrm{N}_{2}$ at $873 \mathrm{~K}$; (b) $50 \%$ mol ethanol $+\mathrm{CO}_{2}$ mixture, heated in $\mathrm{N}_{2}$ at $973 \mathrm{~K}$

Raman spectra of the $\mathrm{SiO}_{2} \mathrm{SBA}-15$ support and the SPION/SiO 2 sample obtained from impregnation of the support using $\mathrm{Fe}\left(\mathrm{NO}_{3}\right)_{3} \cdot 9 \mathrm{H}_{2} \mathrm{O}$ in a $25 \% \mathrm{~mol}$ ethanol $+\mathrm{CO}_{2}$ mixture at $333 \mathrm{~K}$ and 12.0 $\mathrm{MPa}$ and further heated in $\mathrm{N}_{2}$ at $973 \mathrm{~K}$ is shown in Figure S2. Spectra were base line corrected and normalized. $\mathrm{SiO}_{2}$ support showed broad bands at ca. 500, 585 and $650 \mathrm{~cm}^{-1}$. Peak assignment for the different iron oxide phases was based on a previous report by de Faria et al. [1] Peaks at 221 and $289 \mathrm{~cm}^{-1}$ were assigned to $\alpha-\mathrm{Fe}_{2} \mathrm{O}_{3}$. The presence of two Raman bands of similar intensity at ca. 670, 715 indicated the presence of $\gamma-\mathrm{Fe}_{2} \mathrm{O}_{3}$ and not $\mathrm{Fe}_{3} \mathrm{O}_{4}$. The band at $c a .715 \mathrm{~cm}^{-1}$ is related to the vibrational modes of local $\mathrm{Fe}-\mathrm{O}$ near the cation vacancies and it is very weak in $\mathrm{Fe}_{3} \mathrm{O}_{4}$. The intensity ratio of these two bands has been previously used to estimate the $\gamma-\mathrm{Fe}_{2} \mathrm{O}_{3}$ content in partially oxidized $\mathrm{Fe}_{3} \mathrm{O}_{4}$ samples.[2] Broad bands at ca. 350 and $500 \mathrm{~cm}^{-1}$ associated to $\gamma-\mathrm{Fe}_{2} \mathrm{O}_{3}$ were also expected. Raman spectrum of this sample confirmed the presence of $\alpha-\mathrm{Fe}_{2} \mathrm{O}_{3}$ and $\gamma-\mathrm{Fe}_{2} \mathrm{O}_{3}$ in the sample in agreement with the XRD data. 


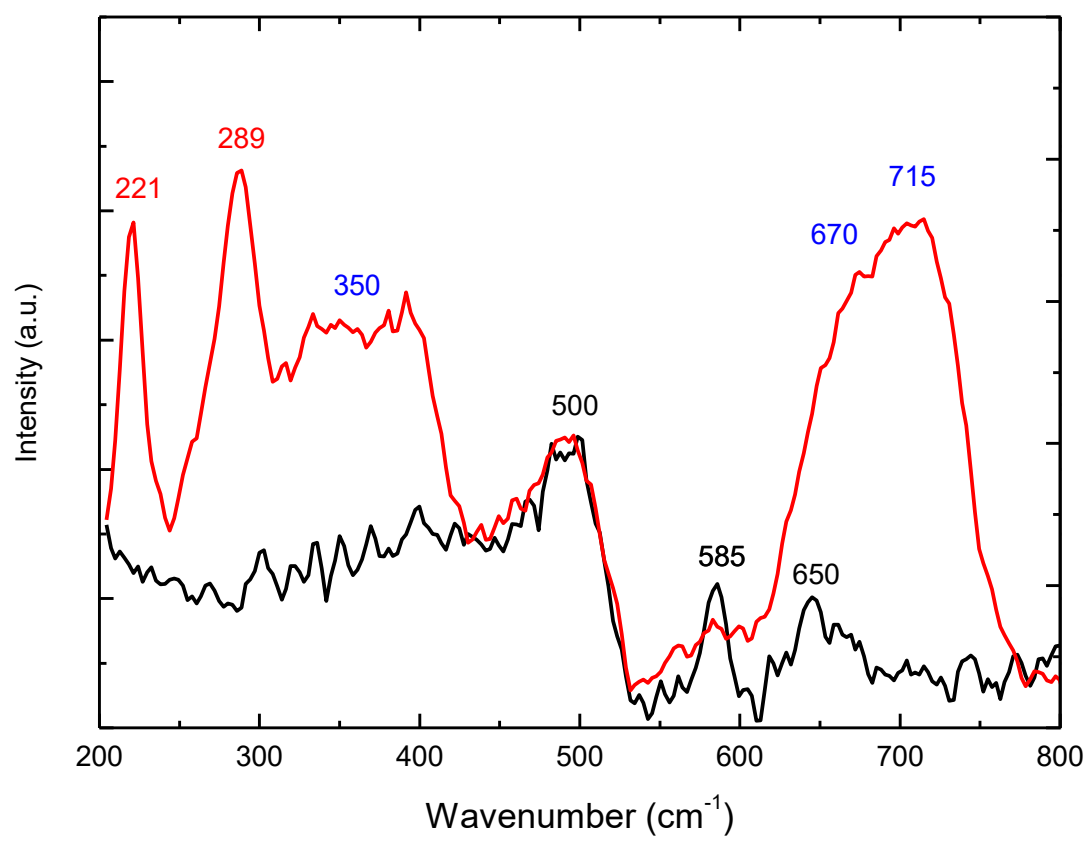

Figure S2- Raman spectra of $\mathrm{SiO}_{2} \mathrm{SBA}-15$ (black line) and an iron oxide/SiO 2 sample (red line) prepared by impregnation of the support with $\mathrm{Fe}\left(\mathrm{NO}_{3}\right)_{3} \cdot 9 \mathrm{H}_{2} \mathrm{O}$ in $\mathrm{CO}_{2}$-expanded ethanol at $333 \mathrm{~K}$ and $12.0 \mathrm{MPa}$ and heated in $\mathrm{N}_{2}$ at $973 \mathrm{~K}$.

[1] D.L.A. deFaria, S.V. Silva, M.T. deOliveira, Raman microspectroscopy of some iron oxides and oxyhydroxides, J. Raman Spectrosc 28(11) (1997) 873-878.

[2] J.W. Long, M.S. Logan, C.P. Rhodes, E.E. Carpenter, R.M. Stroud, D.R. Rolison, Nanocrystalline iron oxide aerogels as mesoporous magnetic architectures, J. Am. Chem. Soc. 126(51) (2004) 16879-16889. 